\title{
Democratização ou assimetria da representação: notas sobre os Conselhos Estaduais de Segurança Alimentar e Nutricional
}

Joana Tereza Vaz de Moura* Lorena Madruga Monteiro**

\section{Resumo}

Os conselhos são inovações institucionais que se estruturam de modo a incorporar representantes da sociedade civil e do Estado. O objetivo desse artigo é discutir a representação política de organizações sociais nesses espaços. Trabalhou-se com a hipótese de que representantes, muitas vezes, se distanciam tanto da base que podem acabar se transformando numa espécie de elite. Questionou-se se apenas a estrutura e os mecanismos democráticos formais desses espaços garantem por si só um padrão plural aos representantes e às práticas de representação, ou se perpetua, através dos recursos sociais e políticos desses representantes, uma representação assimétrica entre as demandas das bases e as suas próprias atuações.

Palavras-chave: conselhos, elites, representação.

\section{Introdução}

Ste estudo analisa a problemática da representação política em Cois conselhos estaduais a partir de um questionamento que está presente em praticamente todos os estudos sobre os novos espaços de participação social: se eles realmente "democratizam a democracia 1 " ou se produzem uma assimetria na representação,

* Professora do Departamento de Políticas Públicas da Universidade Federal do Rio Grande do Norte (Natal). Endereço eletrônico: joanatereza@gmail.com.

桻 Mestre e doutoranda em Ciência Política pela Universidade Federal do Rio Grande do Sul (Porto Alegre). Endereço eletrônico: lorena.madruga@bol.com.br.

1 Referencia-se aqui o título do famoso livro organizado por Boaventura de Sousa Santos Democratizar a democracia: os caminhos da democracia participativa, editado em 2002, por realçar esses espaços como capazes de reconstruir a 
seja caracterizada pela falta de comprometimento do representante, seja pela discrepância entre interesses dos representantes e dos representados, ou pelas características dos representantes que podem reproduzir uma relação de poder baseada em diferenças culturais, políticas, sociais ou econômicas.

Acredita-se que a reflexão proposta seja pertinente para novos estudos sobre representação política, já que procura entender como os representantes atuam em favor dos representados e em que medida essas ações estão em consonância com os interesses destes ou se, ao contrário, existe a concentração do poder por parte de um pequeno grupo no interior dos conselhos, gerando, por vezes, certo distanciamento das demandas da base. Em outras palavras, trata-se de trazer para o debate sobre os conselhos uma nova problemática, considerando-os enquanto lócus de uma nova forma de representação política, cujas características essenciais são: a participação individual, coletiva e voluntária, e a escolha de representantes através de processos variados - eleições, indicações, fóruns (LUCHMANN, 2007).

Em outro momento (MOURA, 2009), já se havia apontado para o fato de que, de forma geral, a representação política exercida por atores da sociedade civil é coletiva e ocorre através de um conglomerado heterogêneo de organizações, que atuam em nome de segmentos específicos, diferindo da representação de interesses pessoais ou de indivíduos. Essas entidades possuem formatos organizacionais os mais variados e relações com seus públicos nem sempre explícitas ou claras, por vezes apenas simbólicas.

Isso posto, uma hipótese que parece bastante razoável sobre o que acontece no espaço dos conselhos é que representantes das diversas organizações que neles participam, muitas vezes, se distanciam da base e podem acabar se transformando numa nova elite política ou, mais que isso, muitas vezes, os conselhos são compostos por "personalidades" ${ }^{2}$ que não têm uma organização que

democracia participativa a partir da luta contra a trivialização da cidadania e em prol de uma vida democrática de alta intensidade.

2 Os Conselhos de Segurança Alimentar e Nutricional são compostos pela representação de especialistas, pesquisadores e profissionais que atuam na 
as sustente, descaracterizando o conceito de representação. Nesse sentido, é de se supor que em muitos conselhos acaba ocorrendo um processo de assimetria da representação.

Como base empírica, tomaram-se como referência dois Conselhos Estaduais de Segurança Alimentar e Nutricional - o do Rio Grande do Sul e o do Ceará - ambos criados em $2003^{3}$ e tendo como especificidade a composição majoritária de organizações da sociedade civil (1/3 de representantes do poder público e $2 / 3$ de representantes da sociedade civil), o que qualifica o debate em torno da representação ${ }^{4}$. Trata-se, portanto, de uma análise crítica do funcionamento desses conselhos, problematizando a questão da representação através dos representantes das mais variadas organizações que os compõem. Acredita-se, nesse sentido, que tal esforço analítico permitirá compreender mais aspectos relacionados à representação desenvolvida por atores da sociedade civil nesses novos espaços de debate sobre políticas públicas.

A escolha por analisar os Conselhos de Segurança Alimentar desses estados federativos deve-se ao fato de ambos apresentarem certa consolidação na sua estrutura e dinâmica de funcionamento, terem em sua composição membros com trajetórias diversas e apresentarem algumas distinções que auxiliam no momento de proceder a uma análise comparativa. Dessa forma, não se pretende estigmatizar a região Nordeste como atrasada e não participativa e um Sul como participativo e moderno, uma vez que se encontram tanto municípios pouco participativos no Sul, quanto municípios bastante ativos no Nordeste do Brasil (AVRITZER, 2007). Entretanto, com

área temática específica. Isso chama a atenção porque se refere a indivíduos, ou seja, dá-se ênfase a um atributo pessoal, que não necessariamente tem o sentido de representação de entidades. Fere-se, assim, segundo teorias, o princípio básico da representação social, que é a escolha de representantes de instituições que devem ser eleitos entre seus pares.

3 O Consea Nacional foi criado em 1993, porém destituído em 1994 para dar lugar ao Programa Comunidade Solidária, sendo recriado em 2003. Os Conseas estaduais e municipais foram criados a partir de 2003, impulsionados pelo Consea Nacional.

4 Com exceção dos Conselhos de Saúde, que têm a composição partilhada entre usuários, técnicos e poder público, os demais conselhos são paritários, ou seja, são compostos por $1 / 2$ de representantes do poder público e $1 / 2$ de representantes da sociedade civil. 
relação ao estado do Ceará, a influência histórica cultural configura um significativo cenário de acordos políticos, consolidados através de alianças familiares extensivas a amigos e parentes, enfim, a todos aqueles que participam do circuito de compromissos. As bases do poder aparecem, assim, sedimentadas e naturalizadas na contínua reprodução das elites dirigentes, o que perdura até um período bem recente (BARREIRA, 1994a). Essa forma de poder, baseada na vinculação direta entre espaços públicos e privados no exercício do poder político, ainda permeia muitas das relações participativas no âmbito dos conselhos, mais especificamente no Consea CE.

Os procedimentos metodológicos utilizados consistiram na realização de entrevistas com os representantes de diferentes tipos de organizações sociais participantes dos Conselhos e análise documental, incluindo as Atas das reuniões dos conselhos, e estão detalhados em Moura (2009). ${ }^{5}$

O texto está organizado em quatro partes principais. Inicialmente, empreende-se, através da literatura especializada, uma reflexão sobre os conselhos no Brasil e o surgimento de novas formas de participação social e política após a implementação dessas inovações institucionais. Em seguida, problematiza-se a questão da representação das bases nos conselhos através dos pressupostos da literatura especializada, para então apresentar as regras e a estrutura dos Conselhos de Segurança Alimentar estudados, especialmente o aspecto da composição desses espaços. Segue-se, finalmente, a análise do perfil dos conselheiros e da questão da representação nos Conselhos de Segurança Alimentar, a qual nos dá subsídios para pensar que tipo de configuração representativa é essa que viabiliza tais estruturas institucionais.

\section{Os conselhos no Brasil: a participação de novos atores no debate público}

A reflexão sobre o surgimento dos Conselhos está diretamente ligada à manifestação popular caracterizada por diversos

5 As entrevistas e documentos utilizados para este artigo são oriundos da pesquisa de campo para a tese de doutorado da primeira autora. 
movimentos sociais no final dos anos 1970 e início dos 1980. Esses movimentos surgiram como novos atores na cena política do País (SADER,1998), capazes de transformar a conjuntura política da época e iniciar um novo processo em busca de maior participação e de novas formas de relação com o Estado.

No Brasil, o debate sobre participação, especificamente no período de transição - entre fins da década de setenta e final dos anos oitenta do século XX -, apresentava-se fortemente marcado pelo contexto político-ideológico da época. Frente à experiência da ditadura militar, o Estado e, mais do que isto, o campo político institucional, passa a ser apresentado como o espaço do autoritarismo, sendo os seus agentes identificados como responsáveis pela opressão e repressão aos interesses sociais excluídos do bloco no poder. Por outro lado, a sociedade civil torna-se o campo da resistência ao poder autoritário, com uma homogeneização discursiva dos seus agentes, então percebidos como democráticos, autônomos e portadores da dinâmica da transformação social e política do país (SILVA, 2003). O marco da transição é a Constituição Federal promulgada em 1988, que "definiu um novo arranjo federativo, com significativa transferência de capacidade decisória, funções e recursos do governo nacional para os estados e, especialmente, para os municípios" (ALMEIDA, 1995, p.92).

Nas legislações ordinárias regulamentadoras da Constituição, foram previstos conselhos colegiados paritários, em geral deliberativos, tendo em sua composição representantes do governo e da sociedade civil, visando controlar e fiscalizar as políticas sociais. Portanto, assistiu-se, ao longo da década de 1990, à proliferação de fóruns, conselhos, comitês e parcerias que buscavam instituir, nos diversos níveis de governo e nas mais variadas áreas de atuação do Estado, novos espaços de participação social.

Não se pode negar que a abertura de novos canais de relacionamento entre sociedade civil e Estado - exemplificada pela implementação dos diversos espaços públicos como conselhos, câmaras setoriais, orçamentos participativos, fóruns etc. -, com suas complexas dinâmicas de funcionamento e uma disputa constante de poder entre diferentes projetos políticos, trouxe uma ampla gama 
e novos conceitos para a compreensão do que estaria acontecendo em países com democracias recentes, uma vez que os conselhos gestores são hoje tão importantes quanto os espaços legislativos na mediação entre sociedade e Estado, e para a representação e participação do interesse coletivo. Esses conselhos têm sido criados desde o nível municipal até o nível federal e passam a ser, em muitos casos, condição para que o município receba determinadas verbas para as chamadas áreas sociais, principalmente nas áreas de saúde, assistência social, educação, direitos da criança e do adolescente etc.

Vários estudos têm atentado para o papel dos conselhos na formulação e implementação de políticas públicas, consequentemente no papel destes para o aprofundamento da democracia (GOHN, 2000; CHAIA \& TÓTORA, 2002; DAGNINO, 2002; TATAGIBA, 2002; SANTOS JR, RIBEIRO \& AZEVEDO, 2004; CORTES, 2005; FUKS \& PERISSINOTO, 2006). Mesmo que apresentem abordagens diferentes, estes estudos apontam para alguns limites e desafios a serem enfrentados pelos conselhos que merecem ser destacados por estarem diretamente relacionados com as questões que perpassam o presente texto.

0 primeiro ponto a ser destacado refere-se à questão específica da representação e indica que os conselhos estudados se constituem como espaços em que os representantes mantêm certo distanciamento da base. O vínculo do representante com os demais participantes das organizações sociais é bastante frágil. Os conselheiros tendem a defender suas próprias opiniões, e não as propostas e posicionamentos resultantes de discussões com os membros envolvidos.

Outro aspecto que merece destaque e que está presente em praticamente todos os estudos sobre os conselhos refere-se à predominância do discurso burocrático e técnico, identificado geralmente com os representantes do poder público e que inibe a atuação dos demais conselheiros. Esta competência privilegia os conhecedores do tema e do "jogo", fazendo com que aqueles que não os conhecem se excluam do debate, muitas vezes até se eximindo da participação nos conselhos. 
Também merece destaque a composição desses espaços. Os estudos indicam que existe um profundo desequilíbrio no processo decisório caracterizado pela composição. Apesar do reconhecimento do governo, ao atribuir a representantes da sociedade civil $50 \%$ ou mais de assento nos conselhos, é oportuno não esquecer que diferenças estruturais influenciam plenamente na construção de interesses coletivos (OFFE \& WIESENTHAL, 1984). O estímulo advindo desses espaços, ao buscarem a participação de organizações da sociedade civil, assegurando-lhes o protagonismo, não parece se ater a essas relações de poder existentes e nem sequer se preocupa com as diferenças estruturais da composição social de um conselho. Além disso, não se define claramente a noção de participação que está sendo proposta, a qual parece estar relacionada somente a um assento no conselho. $\mathrm{O}$ acesso a um assento não implica uma efetiva participação no sentido atribuído tanto por Demo (1994) - "Participar é conquistar o espaço da participação" -, quanto no desenvolvido por Oakley e Marsden (1985), quando se referem ao empowering, cuja interpretação mais comum relaciona-se com a aquisição de poder: poder em termos de acesso e controle de recursos necessários ao desenvolvimento.

Contudo, Abramovay (2001) chama a atenção para a existência de conselhos gestores como uma das mais inovadoras experiências em formas de gestão de recursos públicos. Por mais que os conselhos ainda tendam a reproduzir um ambiente contrário à ampla discussão de assuntos públicos, a sua simples existência coloca pessoas que, até então, não tinham acesso à discussão desses assuntos inseridas no debate de temas antes ausentes de sua vida. Na mesma direção, Lüchmann (2005) elenca alguns fatores que têm sido apontados como relevantes para a implementação e sustentação de experiências participativas, quais sejam: o empenho, vontade e compromisso político-governamental; a capacidade de organização e articulação da sociedade civil; e o desenho institucional. Tudo isso visando à efetivação dos princípios de pluralidade, igualdade e publicidade. Porém, o desafio ainda é a desigualdade social e as diferenças de interesses. 
A dinâmica representativa dos Conselhos torna-se, então, um grande desafio a ser enfrentado por analistas, já que movimentos sociais e demais organizações da sociedade civil têm de apreender e utilizar-se desse novo formato institucional de relação com o Estado. Na medida em que compõem o aparato decisório do Estado, os conselhos articulam no seu espaço os representantes escolhidos em pleitos eleitorais, via partidos políticos (os governantes e seu bloco de ocupantes de cargos de confiança e funcionários), e os representantes da sociedade civil, via os mais diferentes movimentos sociais e organizações (FERRAZ, 2005).

\section{Problematizando a questão da representação}

A despeito de uma visão idealizada da representação, tal como aquela apresentada por Hanna Pitkin (1967, p.221), que a definiu como "um arranjo público, institucionalizado", caracterizado por quatro diferentes dimensões: a formalista, a simbólica, a substantiva e a descritiva (PITKIN, 2006), cada qual representando formas distintas de conexão entre representantes e representados, o objetivo deste trabalho é problematizar, dentro dessa relação, a questão das formas de delegação e a representação dos interesses das bases.

Mesmo que a noção de representação substantiva, na qual os representantes atuam de acordo com as demandas das bases (CORTES, 2007), e a de representação descritiva, na qual os representantes compartilham o mesmo perfil social ou demográfico dos representados, viabilizem, embora de modo normativo, compreender que características e que tipo de atuação dos representantes seriam necessários para um processo representativo efetivo, essas noções não exploram em que medida os representantes se relacionam com seus representados.

Já a concepção de Pierre Bourdieu sobre campo, representação e delegação, por sua vez, mostra-se fundamental para uma maior compreensão da dinâmica, dos impasses e dos desdobramentos da representação nos Conseas, sobretudo porque o autor ressalta a idéia de campo como espaço de conflitos, de embates, 
de desigualdade de força. Da mesma forma, sua reflexão sobre o efeito de censura que o campo político exerce é esclarecedora para a compreensão da postura de alguns conselheiros frente aos "competentes" tecnicamente.

Bourdieu (1989) ressalta que a participação na política implica uma capacidade de conhecimento que foi formulada por um pequeno grupo e que não é acessível a todos, sendo que esse conhecimento é fundamental, pois legitima a entrada ou permanência no campo político:

O campo político, entendido ao mesmo tempo como campo de forças e como campo das lutas que têm em vista transformar a relação de forças que confere a este campo a sua estrutura em dado momento, não é um império: os efeitos das necessidades externas fazem sentir nele por intermédio sobretudo da relação que os mandantes, em consequiência de sua distância diferencial em relação aos instrumentos de produção política, mantém com os seus mandatários e da relação que estes últimos, em consequiência das suas atitudes, mantêm com as suas organizações. O que faz com que a vida política possa ser descrita na lógica da oferta e da procura é a desigual distribuição dos instrumentos de produção de uma representação do mundo social explicitamente formulada: o campo político é o lugar em que se geram, na concorrência entre os agentes que nela se acham envolvidos, produtos políticos, problemas, programas, análises, comentários, conceitos, acontecimentos, entre os quais os cidadãos comuns, reduzidos ao estatuto de consumidores, devem escolher, com probabilidade de mal-entendido tanto maiores quanto mais afastados estão do lugar de produção. (BOURDIEU, 1989, p.164)

Para ele, o campo configura-se como um espaço estruturado de posições, onde os ocupantes têm características diversas. Em relação à representação de grupos, Bourdieu (1989) sinaliza que o campo político é um dos menos livres; as classes dominadas não têm poder de influência, a não ser quando estão organizadas entre si, ou em partidos, associações, grupos de pressão etc. Neste sentido, uma organização permanente é quem deve produzir a representação da classe. Segundo ele, as representações são transcendentes, além de produto de uma construção histórica, porque: 
Quando o ato de delegação é realizado por uma única pessoa em favor de uma única pessoa, as coisas são relativamente claras. Porém, quando uma única pessoa é depositária dos poderes de uma multidão de pessoas, ela pode estar investida de um poder transcendente a cada um dos mandantes. (BOURDIEU, 1990, p.188)

O campo político pode ser então o lugar de concorrência pelo monopólio do direito a falar em nome dos representados, uma vez que o "porta-voz" se apropria da palavra (ou do silêncio) dos representados, procurando se apropriar, também, de sua força (BOURDIEU, 1990). Nesse sentido, quanto mais desfavorecidos econômica e culturalmente os cidadãos, a alternativa que se apresenta a eles é a demissão pela abstenção ou o desapossamento pela delegação, pois:

A delegação representa um ato de magia que permite fazer existir o que não passava de uma coleção de pessoas plurais, uma série de indivíduos justapostos. (...) Quanto mais despossuídas são as pessoas, sobretudo culturalmente, mais elas se vêem obrigadas e inclinadas a confiar em mandatários para ter voz política. De fato, os indivíduos em condição isolada, silenciosos, sem palavra, sem ter nem a capacidade nem o poder de se fazerem ouvir, de se fazerem entender, estão diante da alternativa de calar e de ser falados.

Falar em "demissão por abstenção ou desapossamento por delegação, como alternativa”, sinaliza um processo de escolhas. Em se tratando de "campo político 6 " e de cidadãos e cidadãs comuns, na maioria das vezes a luta cotidiana pela sobrevivência não materializa condições de escolha, tornando-se agentes

6 Para Bourdieu, as lutas políticas ocorrem num campo estruturado e estruturante que se constitui como campo de forças relacional, cujo eixo de relações se dá entre dominantes e dominados, numa dimensão, e entre mandantes e mandatários (e destes com suas organizações), noutra dimensão, todos posicionados diferencialmente em relação aos instrumentos de produção de representações legítimas do mundo social. No campo político, é através da concorrência direta entre os agentes que são gerados "produtos políticos" (problemas, programas, análises, comentários, conceitos, acontecimentos), entre os quais os cidadãos comuns devem "escolher", de tal maneira que a vida política pode ser descrita como um mercado de bens regido pela lógica da oferta e da procura. 
atomizados(as) e não organizados(as). Assim, a categoria "politicamente passivos" pode significar uma estratégia de resistência para atuar no jogo político com armas de que não dispõem. Sem um discurso político próprio, sem domínio do "economês" e com a pressão da sobrevivência, joga-se no espontaneísmo, ora com maior ou menor interesse.

Por outro lado, a aquisição de um capital delegado obedece à lógica da "investidura", fruto de um longo investimento de tempo, de trabalho, de devoção à instituição e/ou ao movimento social a que se pertence. $O$ agente que é investido desse tipo de capital pode não possuir nenhuma outra qualificação, a não ser que a instituição lhe dê esse tipo de treinamento. É a instituição que controla, nesse caso, o acesso à notoriedade pessoal, controlando o tipo de posição que o agente vai assumir no campo político, o tipo de publicidade política que o agente vai usar. Portanto, a aquisição desse tipo de delegação é produto de uma transferência limitada e provisória de:

"um capital detido e controlado pela instituição e só por ela: é o partido que, por meio da ação dos seus quadros e dos seus militantes, acumulou no decurso da história um capital simbólico de reconhecimento e de fidelidade e que a si mesmo se dotou, pela luta política e para ela, de uma organização permanente de membros permanentes capazes de mobilizar os militantes, os aderentes e os simpatizantes e de organizar o trabalho de propaganda necessário à obtenção dos votos e, por esse meio, dos postos que permitem que se mantenham duradouramente os membros permanentes (BOURDIEU, 2002, p.192).

Esse tipo de delegação depende do capital econômico e cultural do agente político, pois a fidelidade a um partido e até a um movimento social é "tanto mais completa quanto mais fraco for o capital econômico e cultural que eles possuíam antes da sua entrada" (BOURDIEU, 2002, p.198). Portanto, a conexão entre capital cultural, indicado na escolaridade, e capital econômico com o tipo de relação que o agente estabelece com a causa e o grupo que representa é significante para a condução do processo representativo. 
Torna-se, assim, interessante analisar os tipos de capitais mobilizados e valorizados pelos agentes que representam os movimentos sociais nos Conselhos para fazer valer as demandas das bases (BOURDIEU, 1998), uma vez que, recentemente, uma série de estudos tem apontado uma relação significativa entre maiores investimentos escolares e militância em uma série de instituições e em causas coletivas (SIMÉANT \& DAUVIN, 2002; MATONTI \& POUPEAU, 2004). Além disso, pode-se situar também a inserção desses representantes pelos diversos conselhos como um engajamento político, se é tomada a noção de carreira política enquanto um processo múltiplo, que envolve uma complexidade de esquemas de ação em variados espaços sociais (FILLIEULE, 2001).

Portanto, em linhas gerais, são essas questões que norteiam nossa reflexão, ainda que de modo preliminar, sobre a representação das bases nos Conselhos. Em outras palavras, trata-se de compreender as relações de poder que se estabelecem nestes espaços, compostos por diferenciados atores portadores de interesses específicos e distintos. Tal perspectiva exige que se analise quem são esses representantes, qual é a configuração dos espaços nos quais participam e como funcionam, para compreender as possibilidades da representação dos atores sociais nessas arenas. Para tanto, é preciso demonstrar se a estrutura, as regras e o funcionamento de um determinado conselho por si só garantem uma relação mais direta entre representantes e representados nessas instâncias decisórias, ou se outras variáveis são mais significativas, como o perfil e as trajetórias militantes desses agentes, no sentido de indicar o distanciamento das bases e um indício de um processo assimétrico de representação.

Cabe agora detalhar o universo dos Conseas, o que prevê a legislação em termos de seu funcionamento enquanto espaço público de articulação da sociedade civil e do Estado, apontando suas responsabilidades, como se dá a construção de agenda e, especialmente, identificar os diferentes atores sociais que fazem parte de sua composição. Neste ponto, o objetivo é mostrar como a configuração institucional dos conselhos pode afetar o papel dos representantes. 


\section{Regras e estruturas dos Conselhos de SAN no Brasil}

Os diferentes arranjos institucionais influenciam o formato da participação social e de representação nos Conselhos? O contexto e as diferentes dinâmicas regionais geram efeitos em suas características e em seus processos representativos? É o que este item busca analisar, uma vez que essas questões sinalizam alguns elementos importantes para compreender a representação, dado que as leis de criação dos conselhos estipulam regras definindo quem pode participar, assim como o tipo de relação estabelecida entre o conselho e o poder público, criando constrangimentos ou abrindo possibilidades de participação na arena pública. Ou seja, trata-se de um processo de mediação entre sociedade e Estado para a representação e participação do interesse coletivo.

Primeiramente, porém, cabe destacar como a causa da Segurança Alimentar construiu-se historicamente no espaço público, uma vez que os Conseas, apesar de terem sido criados nos níveis estadual e municipal, a partir de 2003, resultaram da intensa luta contra a fome e a miséria no Brasil. Segundo Gohn (1997), a carência alimentar foi o estopim de várias mobilizações no país: os movimentos contra a carestia (nas décadas de 10 e 20); a Marcha da Fome, cujos panfletos incentivavam os trabalhadores a realizarem saques a armazéns (1931); a Campanha Popular Contra a Fome (1946); o Movimento de Luta Contra a Carestia e a Passeata da Panela Vazia, que reuniu 500 mil pessoas em São Paulo (1953), a Campanha de Merenda Escolar (1953). Nas décadas de 60 e 70, persistiram os protestos contra a carestia; em 1962, foi criada a Companhia Brasileira de Alimentos (Cobal), em 1973, foi criado o Movimento do Custo de Vida, com forte inserção nos meios populares e apoio da ala progressista da Igreja Católica. Nos anos 80, no contexto da luta pela redemocratização, "a fome apareceu mais associada ao movimento dos desempregados e aos saques, ocorridos nos anos de 1983-4" (GOHN, 1997, p.72).

De acordo com Valente, é apenas no período que compreende a segunda metade da década de 80 e a primeira da década de 90 que se passa da questão da fome à da Segurança Alimentar e Nutricional, pois "o conceito de segurança alimentar ampliava-se, incorporando às esferas da produção agrícola e do abastecimento, as dimensões 
do acesso e da qualidade dos alimentos, como das carências nutricionais" (2002, p.45) ${ }^{7}$. Nesta mesma década, dois acontecimentos foram marcantes para a causa: a criação da Companhia Nacional de Abastecimento (Conab) e a divulgação, pelo IBASE e IBGE, de um estudo intitulado "Mapa da Fome", que apontava 32 milhões de pessoas no Brasil com renda familiar insuficiente sequer para comprar uma cesta básica por mês. Esse estudo desencadeou a famosa campanha de Ação da Cidadania Contra a Fome e a Miséria e Pela Vida - ACCMV, encabeçada por Herbert de Souza, o Betinho, que impulsionou fortemente a criação do Consea Nacional, em 1993. No entanto, apenas a partir de 2002, com a ascensão de Luís Inácio da Silva (Lula) à presidência, o tema da segurança alimentar ganhou novo destaque, já que foi incorporado ao Programa Fome Zero (PFZ), vinculado ao Ministério Extraordinário da Segurança Alimentar (MESA), e criaram-se os Conseas estaduais e municipais.

O caso desses Conseas estaduais originados a partir da conjuntura anteriormente descrita é um exemplo interessante da força da sociedade civil (movimentos sociais, organizações locais ou nacionais, partidos políticos, sindicatos, ONGs, entre outros atores sociais) em reivindicar espaços para aumentar a participação social, resultando numa configuração que privilegiasse atores da sociedade civil em sua composição. Compreendeu-se que a maior parte da composição (2/3) deveria ser de representantes da sociedade, visando garantir sua legitimidade, e $1 / 3$ de representantes do Estado. Entretanto, essa condição majoritária dada à sociedade civil não pode ficar reduzida à dimensão numérica, como já mostraram diversos estudos sobre os conselhos (TATAGIBA, 2002; ABRAMOVAY, 2001; CHAIA \& TÓTORA, 2004; SANTOS JUNIOR, et al., 2004). O interessante é tratar a dimensão política dessa composição, problematizando as relações entre sociedade e Estado.

Abramovay (2001) chama a atenção para a desigualdade da distribuição de poder. Apesar da concordância do governo em atri-

7 As primeiras noções do conceito de segurança alimentar aparecem na proposta intitulada "Política Nacional de Segurança Alimentar", elaborada por especialistas coordenados por José Gomes da Silva, no âmbito do chamado Governo Paralelo instituído pelo Partido dos Trabalhadores, após a derrota eleitoral de 1989. 
buir a representantes da sociedade civil 2/3 de assento nos Conseas, é oportuno não esquecer que diferenças estruturais influenciam plenamente na construção de interesses coletivos (OFFE \& WIESENTHAL, 1984). O documento do Consea Nacional, ao estimular que "a sociedade participe da formulação, execução e acompanhamento de políticas de Segurança Alimentar e Nutricional" e considerar "que a organização da sociedade é uma condição essencial para as conquistas sociais e para a superação definitiva da exclusão" (CONSEA, 2007), não parece se ater às relações de poder existentes na sociedade e nem sequer se preocupa com as diferenças estruturais da composição social de um conselho. Portanto, essa situação possui um caráter desafiador que deve se melhor compreendida. Por isso, é importante conhecer os Conseas no âmbito de sua institucionalização, tornando-se necessário trazer informações acerca de suas atribuições e de sua composição.

Os Conseas estudados, apesar de tratarem do mesmo tema, têm diferentes formas de organização e funcionamento, e isso é determinado por suas configurações. Observou-se que, mesmo que tenham origens e objetivos aparentemente semelhantes, apresentam configurações diferenciadas. Mesmo assim, a criação dos Conseas sinaliza algumas questões interessantes para entender a representação e como determinados conselheiros foram escolhidos, fortalecendo a hipótese de que uma "elite" estaria sendo criada dentro desses conselhos.

O primeiro fator que merece destaque refere-se ao caráter consultivo dos Conseas. O fato de serem reconhecidos e haver legislação que lhes dá poder não garante que as proposições sejam acatadas pelo poder público, uma vez que eles têm apenas o papel de aconselhamento. Nesse caso, os tradicionais executores de políticas públicas continuam com o poder. $O$ processo decisório nesses Conselhos é fragilizado devido a esse caráter, e vai depender de o poder público aceitar ou não as propostas por eles enviadas. Mais ainda, pode depender de contatos pessoais entre alguns conselheiros que têm acesso direto com o poder público, fortalecendo o seu caráter personalista e individualista de reivindicar.

O segundo fator que limita uma atuação mais propositiva dos Conselhos é a composição desses espaços. 


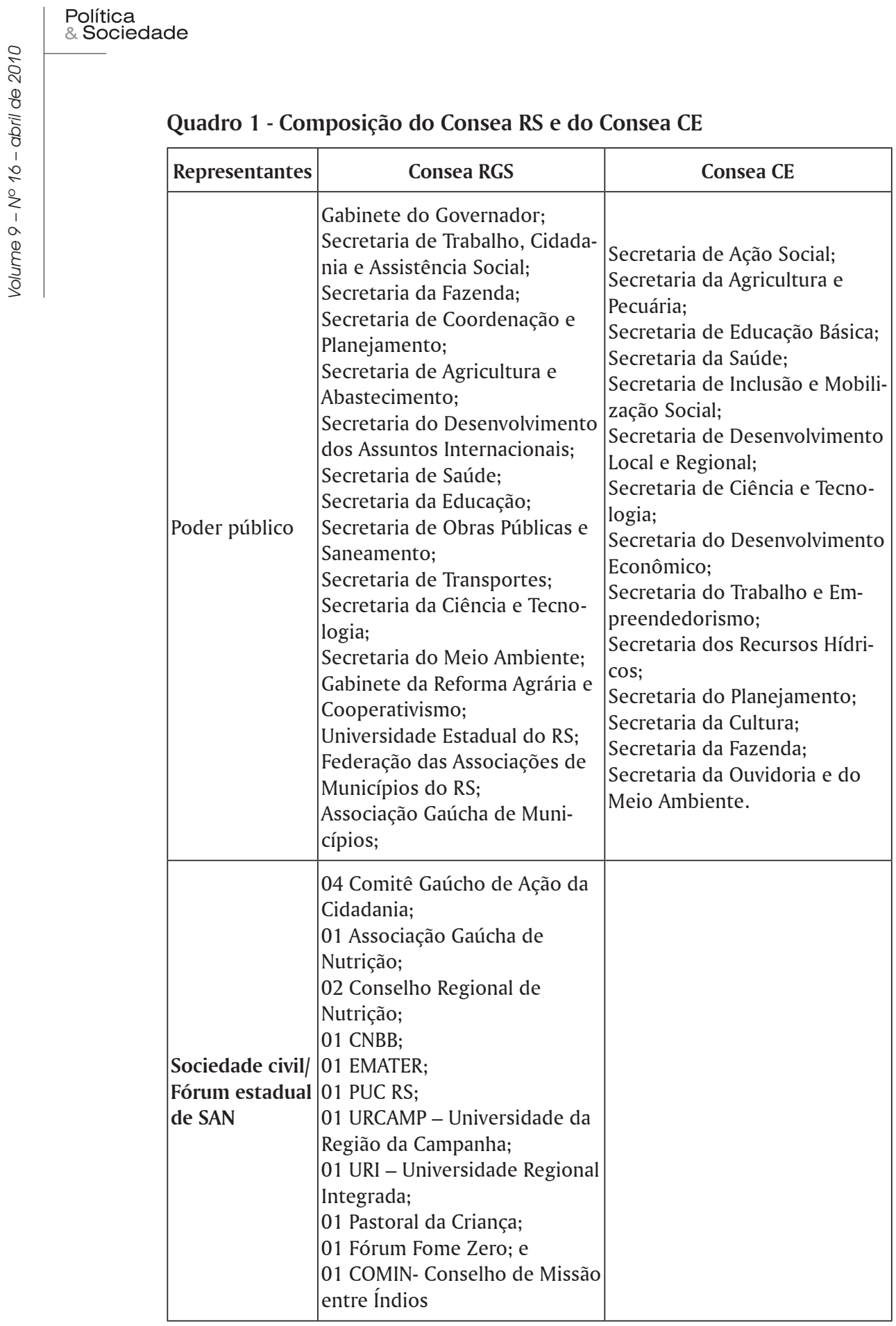


Democratização ou assimetria da representação: notas sobre os Conselhos Estaduais de Segurança Alimentar e Nutricional

Joana Tereza Vaz de Moura • Lorena Madruga Monteiro

\begin{tabular}{|c|c|c|}
\hline Representantes & Consea RGS & Consea CE \\
\hline $\begin{array}{l}\text { Sociedade civil } \\
\text { nominada* }^{*}\end{array}$ & $\begin{array}{l}\text { FIERGS - Federação das Indús- } \\
\text { trias do Estado do Rio Grande } \\
\text { do Sul; } \\
\text { FARSUL - Federação da Agricul- } \\
\text { tura do Estado do Rio Grande } \\
\text { do Sul; } \\
\text { FECOMERCIO - Federação do } \\
\text { Comércio; } \\
\text { FEDERASUL - Federação das } \\
\text { Associações Comerciais e de } \\
\text { Serviços do Rio Grande do Sul; } \\
\text { CUT-RS; } \\
\text { Força Sindical; } \\
\text { FETAG - Federação dos Traba- } \\
\text { lhadores na Agricultura; } \\
\text { Via Campesina; } \\
\text { FETRAF-SUL - Federação dos } \\
\text { Trabalhadores na Agricultura } \\
\text { Familiar da Região Sul; } \\
\text { FRACAB - Federação Rio- } \\
\text { Grandense de Associações } \\
\text { Comunitárias e de Moradores } \\
\text { de Bairros; } \\
\text { OCERGS - Organização das } \\
\text { Cooperativas do Rio Grande } \\
\text { do Sul; } \\
\text { Lions Club RS; } \\
\text { Rotary Club RS; } \\
\text { UEE - União Estadual dos } \\
\text { Estudantes; } \\
\text { UGES - União Gaúcha dos } \\
\text { Estudantes; } \\
\text { Associação Rio Grandense de } \\
\text { Fundações. }\end{array}$ & $\begin{array}{l}\text { Confederação Nacional dos } \\
\text { Bispos do Brasil; } \\
\text { Federação das Indústrias do } \\
\text { Estado do Ceará - FIEC; } \\
\text { Federação do Comércio- FECO- } \\
\text { MÉRCIO; } \\
\text { Federação da Agricultura do } \\
\text { Estado do Ceará - FAEC; } \\
\text { Federação dos Trabalhadores } \\
\text { da Agricultura do Estado do } \\
\text { Ceará - FETRAECE; } \\
\text { Assembléia Legislativa; } \\
\text { Associação dos Prefeitos do } \\
\text { Estado do Ceará - APRECE; } \\
\text { Serviço Brasileiro de Apoio à } \\
\text { Pequena e Micro Empresa - } \\
\text { SEBRAE; } \\
\text { Universidade Federal do Ceará } \\
\text { - UFC; } \\
\text { Universidade Estadual do Ceará } \\
\text { - UECE; } \\
\text { Comitê de Entidades no } \\
\text { Combate à Fome e Pela Vida - } \\
\text { COEP/CE; } \\
\text { Fórum Cearense de Segurança } \\
\text { Alimentar e Nutricional; } \\
\text { Associação Cearense de Super- } \\
\text { mercados - ACESU; } \\
\text { Federação das Entidades Co- } \\
\text { munitárias do Estado do Ceará } \\
\text { - FECECE; } \\
\text { Banco do Nordeste; } \\
\text { Central Única dos Trabalhado- } \\
\text { res - CUT; } \\
\text { Federação dos Jovens Empresá- } \\
\text { rios do Ceará - FAJECE; } \\
\text { Rotary Club; } \\
\text { Lions Club. }\end{array}$ \\
\hline
\end{tabular}

* De acordo com o Regimento Interno do Consea CE, a categoria sociedade civil é definida como representação de instituições públicas e organizações não-governamentais.

A presença forte da sociedade civil no Consea RS, como ilustra o quadro acima, tem relação com o processo que levou à sua criação, o que fez com que o seu desenho institucional fosse diferente 
de muitos outros conselhos estaduais. No Consea RS, metade da cota destinada aos representantes da sociedade civil, 1/3 dos 2/3 destinados a organizações desse tipo, é escolhido por seus pares, através do Fórum Estadual de Segurança Alimentar e Nutricional. O outro $1 / 3$, conhecido como "sociedade civil nominada", é escolhido pelo poder público. Portanto, existe esta separação entre organizações da sociedade civil, que são divididas entre aquelas que fazem parte do Fórum Estadual de SAN e as que fazem parte da chamada sociedade civil nominada. Os 16 representantes advindos do Fórum representam-no no Conselho e foram escolhidos dentre aqueles indivíduos que tinham maior militância na área. Entretanto, alguns outros integrantes foram indicados pelo próprio coordenador do Fórum, a partir de contatos com pessoas que não faziam parte deste. Isso revela que o processo de escolha dos representantes no Consea RS é bastante complexo, conforme ilustra o depoimento de uma representante do Fórum:

Como eu sempre tive essa militância no Fórum e nas reuniões e se escolheu algumas pessoas que tinham essa militância e que participavam do Fórum (inclusive eu na época era do fórum técnico metropolitano de Segurança Alimentar), eu fui escolhida. Quem coordenava o Fesans, na época, era o atual presidente do Consea RS, e ele tinha uma característica pessoal de ver as pessoas que não participavam do Fórum e que eram importantes para estarem no Consea RS e daí ele apresentava os nomes para o Fórum e esse aceitava ou não e, então, caso o Fórum aceitasse, essa pessoa era indicada para participar no Consea RS.

Essa fala aponta uma dificuldade vivenciada pelo Consea RS com relação à sua composição, corroborando com a hipótese que se trabalha nesse artigo, uma vez que um indivíduo (atual presidente) acaba por escolher as pessoas para participar do Conselho, independentemente de fazerem parte de organizações ou não. Esse aspecto demarca a posição dos indivíduos neste Conselho que, indicados pelo presidente, se sentem legitimados para falar em nome de uma parcela da população que não tem acesso à segurança alimentar.

Ao analisar a composição do Consea CE, o problema da dificuldade de separação entre sociedade civil e Estado aparece claramente. Apesar das especificidades regionais, a criação do Consea 
CE se deu de forma muito semelhante à do Consea RS, embora o desenho institucional marque uma grande diferença. $O$ depoimento da ex-presidente do Consea CE exemplifica esse processo:

A gente pode intervir muito pouco na escolha de quem iria participar do Consea. Porque a lei, ou melhor, a lei não, o decreto, porque aqui não é lei, é decreto, foi feito pelo Governo, enviado para Assembléia e a gente não teve muita opinião e nem influência. O que a gente conseguiu foi colocar o Fórum Estadual de Segurança Alimentar, e pressionar um pouco para alguém das Pastorais, mas no mais foi eles que decidiram, inclusive a representação da sociedade civil não é boa.

Segundo Avritzer (2007), a presença dos movimentos sociais urbanos no Ceará não foi significativa, durante o período da redemocratização, tal como foi no Rio Grande do Sul. Teve forte presença no estado o chamado mudancismo, um movimento de reforma política e administrativa centrado na organização do Estado. Esse movimento, criado com a chegada do grupo político liderado por Tasso Jereissati e Ciro Gomes ao poder no estado, contribuiu de muitas maneiras para a criação da sociedade civil, incentivando a criação de diversos tipos de organizações civis, principalmente as de produtores (TENDLER apud AVRITZER, 2007). Nesse sentido, percebe-se um caso de participação onde o Estado foi o maior incentivador.

Foi sob o signo da ruptura, expresso no slogan "governo das mudanças", que o grupo de empresários liderados por Tasso Jereissati (hoje expoente nacional do Partido da Social Democracia Brasileira PSDB) ocupou a cena política cearense. Tal proposta, ancorada não só em grupos empresariais, mas também em intelectuais, partidos de esquerda e outros setores organizados da sociedade civil, impôs-se como "nova forma de fazer política". Essa forma, baseada em uma representação simbólica temporal, definida a partir de um "antes e depois”, apresentou uma oposição clara às formas tradicionais de poder aglutinadas em torno do coronelismo (BARREIRA, 1994a). Percebe-se claramente a diferença em relação à sociedade civil do Rio Grande do Sul, que emerge por contestação a um estado autoritário, ao contrário do que ocorre no Ceará, onde emerge a partir de incentivos estatais, ficando, muitas vezes, refém do Estado. 
De acordo com o Regimento Interno do Consea CE e com o decreto n. 27.008, de 15 de abril de 2003, publicado no Diário Oficial do Estado, em 17 de abril de 2003, o Consea CE é "composto por trinta e cinco membros designados pelo Governador do Estado, sendo quatorze representantes de órgãos da Administração Estadual e vinte e um representantes de outras organizações, dentre organismos federais, da sociedade civil e de cooperação internacional". Ainda, nessa composição percebe-se claramente uma forte presença da área patronal, conforme demonstra a ex-presidente do Consea CE em seu depoimento:

Hoje no Consea tem que a maioria é sociedade civil, mas sociedade civil entre aspas, porque muitos dessa sociedade civil são aliados ao Governo. Por exemplo, o Rotary, o Lyons, são dois que servem o Governo. $\mathrm{O}$ empresariado da sociedade civil, área patronal, está muito representado (comércio, indústria. agricultura); além disso, tem a FIEC, a Associação dos Jovens Empresários, então a área patronal está muito forte, e, por outro lado, nem todos eles participam.

Para muitos, ainda faltam representações de organizações indígenas, da Associação Brasileira de ONG's (ABONG), de movimentos populares e sindicais. Para o representante da Cáritas, é preciso rever a composição do Consea $\mathrm{CE}$, porque muitas entidades não sabem o que é segurança alimentar. Conforme sua fala:

Aqui no Ceará o que eu percebo é que a maioria das instituições não tem discussão e nem trabalhos diretos com a segurança alimentar. Eu vejo que somente a Cáritas tem esse trabalho. Quem são as outras instituições? Por exemplo, a Universidade que tem feito algumas discussões, tem pautado alguns temas, mas que está lá. A Fiec, o Rotary que é um monte de gente que diz que tem trabalhado com segurança alimentar, mas que é distribuir sopas, mais a questão do assistencialismo, mais compensatória, que acaba não emancipando as pessoas.

Tal afirmativa tem relação com a questão de que a indicação dos conselheiros e suas respectivas organizações pelo poder público fere o próprio sentido da representação da sociedade civil, na medida em que, em muitos casos, só os atores considerados confiáveis pelo poder público são chamados a participar (SANTOS, 2004). Por 
isso observa-se que todos os esforços da sociedade civil no Consea CE são para que o presidente seja sempre um de seus representantes. Enquanto no Consea Nacional e no Consea RS, isso consta do Regimento interno, no Consea CE isso ainda está em disputa. Sobre este ponto, a ex-presidente do Consea CE e representante da UFC considera que: "Quando o presidente é da sociedade civil, ele tem mais autonomia e mais independência; se a gente quer propor políticas e exercer o controle social é muito melhor que ele seja coordenado e orientado a partir da sociedade civil."

Percebe-se que no Consea RS existe uma forte predominância de indivíduos ligados a movimentos sociais, sindicatos, federações e/ou confederações, impulsionando o debate sobre SAN, já que são, em sua maioria, representantes do Fórum estadual de SAN. Nas últimas décadas do século XX e neste século, estas organizações têm tido posições de liderança no alargamento de questões políticas que tem a ver com direitos, em todos os sentidos, desde os direitos individuais até questões relacionadas com a biodiversidade. Deve-se a elas a incorporação de temas no debate público que até então tinham ficado de fora e que, na maioria das vezes, não eram sequer considerados como legítimos (PINTO, 2003).

O Consea CE, por sua vez, tem muito menos representantes da sociedade civil que o Consea RS; são somente 19. Como no Consea RS, no do Ceará a presença de movimentos sociais, confederações, associações e sindicatos é considerável em relação a outros setores da sociedade civil. Entretanto, neste as Confederações e associações são referentes à área patronal, o que o diferencia substancialmente daquele. Por fim, é importante assinalar que outro fator limitante é com relação à sua autonomia. O Consea RS tem um caráter um pouco mais desvinculado do Governo, pelos projetos políticos das próprias organizações representantes da sociedade civil, diferentemente do Consea CE, que tem, entre os representantes da sociedade civil, várias pessoas ligadas ao Governo.

Portanto, pode-se considerar que a busca por uma composição mais plural e diversificada é um processo constante, dependente do entendimento tanto do Conselho quanto do poder público de quais seriam os grupos sociais legitimados para falar em nome da SAN. Neste sentido, o item abaixo explora, mesmo que preliminarmente, a 
questão da formação desses conselheiros e como eles se relacionam com os seus representados, a fim de problematizar em que medida ocorre um processo de "elitização" nos espaços dos conselhos.

\section{A atuação e a trajetória dos conselheiros: um processo assimétrico de representação?}

Como foi visto, a configuração institucional, além, é claro, das dinâmicas regionais, é um fator que condiciona a representação social nesses conselhos, porque as leis e/ou decretos de criação dos Conseas sinalizam elementos importantes para a sua análise. Além disso, para a reflexão proposta, é necessário delimitar de que modo a falta de vínculos do representante com a base combinada à sua trajetória política reforça o argumento da emergência de um processo de assimetria de poder e de representatividade no interior dos conselhos.

Para tanto, inicialmente analisou-se nos dois Conseas a temática da representatividade, ou seja, verificaram-se os vínculos institucionais dos indivíduos com as suas organizações sociais a partir do modo de escolha dos representantes e dos meios de discussão utilizados pelos conselheiros para se relacionarem com a sua base. Em seguida, fez-se uma breve apresentação da trajetória dos conselheiros, relacionando-a com a questão da representatividade, a fim de compreender em que medida está-se passando por um processo de distanciamento da base.

Boa parte da literatura sobre os conselhos enfatiza a assertiva de que o vínculo institucional entre conselheiros e organizações sociais é um dos aspectos centrais para que os conselhos se efetivem como espaços plurais e legítimos de representação de interesses de segmentos sociais. É importante notar, segundo Santos (2004), que, para que a co-gestão entre a sociedade civil e o Estado, na formulação de políticas públicas, se traduza realmente num aprofundamento da democracia, é necessária a garantia de um espaço de consulta às bases, tanto na eleição do representante, quanto nas definições das posições a serem tomadas. É muito importante definir como os diferentes atores da sociedade civil, agrupados em blocos, são autorizados para falar em nome de determinados grupos específicos ou de pessoas. 
Nos Conseas observou-se a presença de representantes que fazem parte de movimentos sociais e de fóruns que estiveram diretamente ligados à luta pelo direito à alimentação e à redução da fome e da miséria nos últimos anos. Tornaram-se, desta forma, legitimados para falar em nome de uma grande parcela da população que não tem acesso à alimentação saudável e, por este motivo, foram escolhidos para integrar os Conseas. Desse modo, tendo em mente estas considerações, analisou-se a representatividade nos Conseas através de duas variáveis: a forma como o representante foi escolhido e o meio utilizado pelo representante para consultar a base.

Com esse objetivo, utilizaram-se duas formas no processo de escolha do conselheiro por sua instituição: a centralizada e a coletiva. A prática centralizada na escolha dos representantes é expressa pela indicação direta do presidente da organização ou pela indicação dos Governadores dos estados do Rio Grande do Sul e do Ceará. A prática coletiva refere-se à escolha dos conselheiros por reuniões da direção ou em espaços ampliados e abertos a todos os associados, como as assembléias, plenárias ou fóruns de SAN. Com relação a estes últimos, Santos $(2004$, p. 133) assinala que "a eleição de organizações representantes da sociedade civil em fóruns próprios aponta para um tipo de representação que vai além da própria instituição do conselheiro, tendo em vista que este precisa se legitimar diante de um segmento social".

Acredita-se que os meios utilizados pelos representantes para consultar a base são instrumentos essenciais para a compreensão da legitimidade da representação, tendo em vista a centralização ou descentralização das decisões e, até mesmo, para verificar a importância que as temáticas abordadas nos Conseas têm no interior das organizações (SANTOS, 2004). Os mecanismos utilizados podem ser as reuniões de direção e/ou as reuniões/plenárias das instituições.

Os dados da pesquisa revelaram a existência de um vínculo institucional entre os conselheiros e as organizações sociais do Consea do Rio Grande do Sul, caracterizado pela escolha dos representantes em fóruns próprios, como no caso do Fórum estadual de SAN RS, que escolhe 1/3 dos conselheiros; ao contrário do que acontece no Consea CE, em que os representantes, em sua maioria, são escolhidos pela forma centralizada. Como se demonstra no quadro abaixo: 


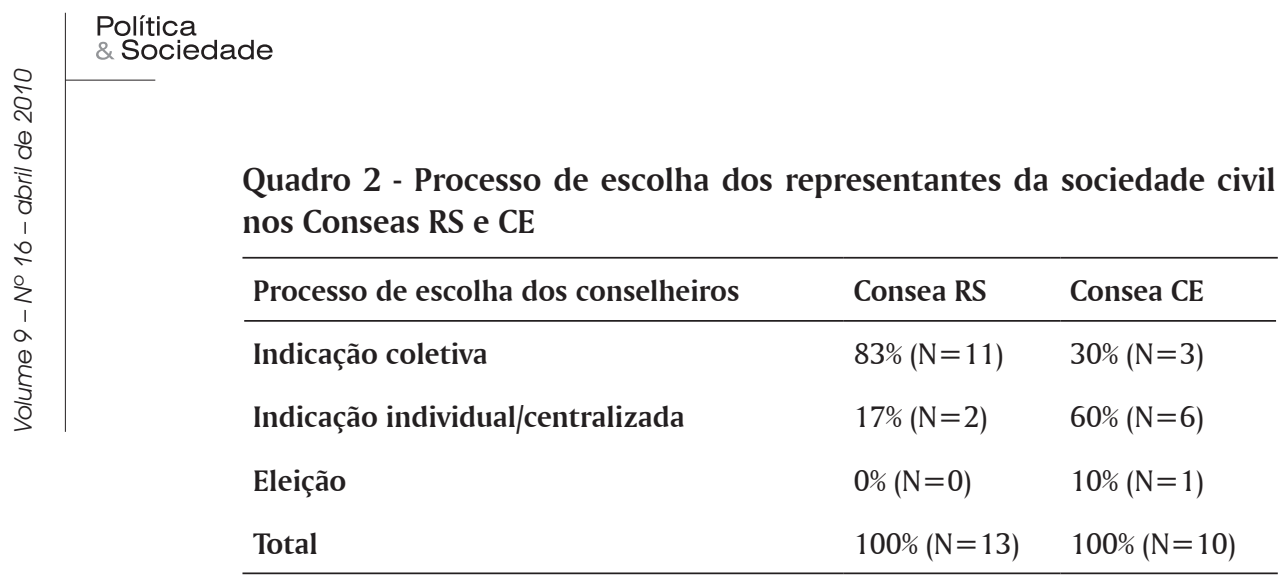

Fonte: dados das entrevistas (2007) in Moura (2009).

Percebe-se que o vínculo institucional entre os conselheiros e as organizações sociais no Consea CE é mais frágil, já que $60 \%$ dos entrevistados foram escolhidos mediante a prática centralizadora, seja pela indicação direta do Presidente da organização, seja pela indicação do Secretário estadual. Mesmo somando os indicados de forma coletiva com aqueles conselheiros que declararam ter sido escolhidos via eleição, este número ainda fica aquém daqueles indicados de forma centralizada. Isso revela a fragilidade da relação dos representantes com a sua base.

A representatividade também foi medida pela relação estabelecida entre representante e representado, isto é, analisando-se se o representado legitima a atuação dos seus representantes, através da realização de reuniões, de encontros ou por outros meios. O Quadro 03 apresenta essas informações.

Quadro 3 - Meios utilizados pelos representantes da sociedade civil para consulta à base nos Conseas RS e CE

\begin{tabular}{lll}
\hline Meios utilizados para consulta à base & Consea RS & Consea CE \\
\hline Não têm & $23 \%(\mathrm{~N}=3)$ & $30 \%(\mathrm{~N}=3)$ \\
Reuniões & $54 \%(\mathrm{~N}=7)$ & $50 \%(\mathrm{~N}=5)$ \\
Outros (eventos, e-mails, relatórios) & $23 \%(\mathrm{~N}=3)$ & $20 \%(\mathrm{~N}=2)$ \\
Total & $100 \%(\mathrm{~N}=13)$ & $100 \%(\mathrm{~N}=10)$ \\
\hline
\end{tabular}

Fonte: dados das entrevistas (2007) in Moura (2009). 
Os mecanismos de consulta à base citados como mais utilizados foram as reuniões/plenárias com os membros da instituição. Alguns conselheiros citaram a troca de emails como uma fonte de relacionamento com a base, e outros ainda indicaram o encontro em eventos. Entretanto, essa é uma questão recorrente do problema da representação política: a dificuldade de relacionamento com a base. Quais seriam os melhores meios para se relacionar com a base? As reuniões periódicas são os principais mecanismos de informação, fiscalização e acompanhamento das decisões do Consea, para os representados. É nessas reuniões que os integrantes das entidades conseguem debater e apresentar demandas para que o representante leve para o Consea. Os outros meios utilizados (e-mails, eventos, relatórios) só conseguem dar conta do feedback, isto é, os integrantes da entidade só acompanham as decisões num momento posterior, não conseguindo ter interferência na atuação do representante. $O$ depoimento de um representante do Fórum estadual de SAN do RS, também participante da ONG CAMP, revela a dificuldade de se articular com a base e de essa relação se dar somente em alguns eventos, como abaixo:

Nós acabamos indo para o Consea, muito como representação das ONGS, da ABONG (rede de ONGs). Porque a gente enquanto Camp participou muito da organização do Fórum Social Mundial, principalmente os que foram em Porto Alegre. Em função dessa relação com a $A B O N G$ a gente chega no Consea via Fesans, pela representação da ABONG.(...) A gente tem a vantagem de ser uma instituição que dialoga com todas as matizes, com as diferentes ideologias. Quando a gente chama, o pessoal se reúne, mas acaba sendo uma atuação residual. Só acontece quando tem conferência ou quando é uma mobilização específica.

Outra conselheira indicada pelo Fórum revela em sua entrevista essa complexidade da representação.

No Fórum eu represento a Associação Gaúcha de Nutrição, que tem de sócios, contando nutricionistas e técnicos, umas 280 pessoas. Eu sou a vice-presidente. A gente tem reuniões da diretoria mensais, e tem vários conselhos, que também vão se reunindo ao longo do mês e deliberando as suas demandas e depois a gente 
faz reuniões, palestras, encontros e discute sobre o tema. A gente traz gente para palestrar sobre o tema. Uma relação de fazer coisas científicas, passar conhecimento.

É relevante notar que alguns entrevistados responderam não ter um meio de comunicação com a base $(23 \%$ e $30 \%$, respectivamente para os Conseas RS e CE). Isso pode ser explicado pelo formato da composição desse conselho, em que participam algumas entidades patronais (sociedade civil nominada no Consea RS e diversas entidades ligadas ao empresariado no Consea CE). Os conselheiros dessas entidades não precisam da autorização da base para defender os seus pontos de vistas e/ou concepções. Offe e Wisenthal (1984) já chamavam a atenção para esse aspecto. Para eles, enquanto os capitalistas têm um poder de sanção individual, os trabalhadores dependem inteiramente de suas organizações, ou seja, as lideranças das organizações do capital têm uma maior capacidade de acionar sanções do que as do trabalho, muito mais vinculadas aos membros da base e com menor autonomia.

Outro aspecto que tem relação com a hipótese que se trabalha nesta análise de que ocorre certa assimetria da representação nos Conseas é que os representantes distanciam-se da base, e em alguns casos não constroem nenhum tipo de relação com ela. Isso se verificou quando se contrasta o processo de escolha dos representantes com os meios utilizados pelos representantes da sociedade civil para consultar as bases. Aqueles cuja representação foi decidida coletivamente tendem a consultar sua base através de reuniões, além de outras formas como relatórios, e-mails, comunicações, etc. Já aqueles que foram nomeados (indicação individual, centralizada) não consultam suas bases, e quando o fazem é através de e-mails, eventos, relatórios, etc.

Esta questão do distanciamento das bases pode ter relação com os tipos de capitais que dispõem os diferentes conselheiros, a exemplo dos capitais escolares. Dentre os conselheiros, tanto do Consea RS, quanto no do Ceará, analisados, destaca-se o fato de que a maioria possui ensino superior e estudos pós-graduados. Como se demonstra no quadro abaixo: 
Quadro 4 - Formação escolar dos conselheiros entrevistados nos dois Conseas

\begin{tabular}{lll}
\hline Escolaridade & $\begin{array}{l}\text { Conselheiros } \\
\text { Consea RS }\end{array}$ & $\begin{array}{l}\text { Conselheiros } \\
\text { Consea CE }\end{array}$ \\
\hline Ensino fundamental & $7,6 \%(\mathrm{~N}=1)$ & $10 \%(\mathrm{~N}=1)$ \\
Ensino médio incompleto & $7,6 \%(\mathrm{~N}=1)$ & \\
Ensino técnico & $7,6 \%(\mathrm{~N}=1)$ & \\
Apenas Ensino superior completo & $46 \%(\mathrm{~N}=6)$ & $60 \%(\mathrm{~N}=6)$ \\
Pós- Graduação (Mestrado e doutorado) & $31 \%(\mathrm{~N}=4)$ & $40 \%(\mathrm{~N}=4)$ \\
Total & $100 \%(\mathrm{~N}=13)$ & $100 \%(\mathrm{~N}=10)$ \\
\hline
\end{tabular}

Fonte: dados das entrevistas (2007) em Moura (2009).

Nesta direção, é importante registrar que a maioria possui titulação escolar em áreas relacionadas com os eixos de discussão técnica dos Conseas (Nutrição, Ciências Sociais, Agronomia, Direito, Economia, Veterinária), embora alguns casos apresentem formações escolares em outras áreas (Teologia, Letras, etc). Portanto, pode-se dizer que, em termos de formação escolar, os representantes das diversas entidades nos Conseas destacam-se pelo seu conhecimento técnico, como especialistas da temática de segurança alimentar, não pelo seu relacionamento com suas bases.

Tal argumento clarifica-se quando contrastamos as trajetórias escolares dos representantes com sua trajetória associativa. Embora se tenha poucos dados que possibilitem uma inferência conclusiva, é possível indicar que quanto maior a escolarização dos conselheiros, menor militância associativa em geral, conforme os quadros seguintes: 
Quadro 5 - Trajetória associativa e formação escolar dos conselheiros da sociedade civil

\begin{tabular}{|c|c|c|c|}
\hline $\begin{array}{l}\text { Entidade que } \\
\text { representa }\end{array}$ & $\begin{array}{l}\text { Entidade que repre- } \\
\text { senta no Fórum }\end{array}$ & $\begin{array}{l}\text { Demais entidades de que partici- } \\
\text { pou e/ou participa }\end{array}$ & $\begin{array}{l}\text { Formação } \\
\text { escolar }\end{array}$ \\
\hline $\begin{array}{l}\text { Fórum estadual } \\
\text { de SAN RS }\end{array}$ & Ação da Cidadania & Movimento social & Doutorado \\
\hline $\begin{array}{l}\text { Fórum estadual } \\
\text { de SAN RS* }\end{array}$ & $\begin{array}{l}\text { Conselho de Segurança } \\
\text { Alimentar e Desenvol- } \\
\text { vimento de Canoas }\end{array}$ & $\begin{array}{l}\text { Ação da Cidadania; movimento } \\
\text { negro; Associação de Bairro; } \\
\text { Conselho de Saúde }\end{array}$ & $\begin{array}{l}\text { Ensino Fun- } \\
\text { damental }\end{array}$ \\
\hline $\begin{array}{l}\text { Fórum estadual } \\
\text { de SAN RS }\end{array}$ & Ação da Cidadania & Não citou nenhum outro & Doutorado \\
\hline $\begin{array}{l}\text { Fórum estadual } \\
\text { de SAN RS }\end{array}$ & CNBB & Não citou nenhum outro & Mestrado \\
\hline $\begin{array}{l}\text { Fórum estadual } \\
\text { de SAN RS }\end{array}$ & EMATER & Não citou nenhum outro & Bacharel \\
\hline $\begin{array}{l}\text { Fórum estadual } \\
\text { de SAN RS }\end{array}$ & EMATER & $\begin{array}{l}\text { Consea Nacional, Conselho de } \\
\text { Saúde, Partido Político, Movi- } \\
\text { mento Eclesial de Base; ONG; } \\
\text { movimento feminista }\end{array}$ & Bacharel \\
\hline $\begin{array}{l}\text { Fórum estadual } \\
\text { de SAN RS }\end{array}$ & ONG CAMP & $\begin{array}{l}\text { ONG; movimentos sociais; partido } \\
\text { político; TALHER }\end{array}$ & Bacharel \\
\hline $\begin{array}{l}\text { Fórum estadual } \\
\text { de SAN RS }\end{array}$ & Fórum Fome Zero & $\begin{array}{l}\text { Movimento Negro; Conselho de } \\
\text { Saúde; Conselho de Participação e } \\
\text { Desenvolvimento da Comunidade } \\
\text { Negra RS; ONG }\end{array}$ & $\begin{array}{l}\text { Ensino médio } \\
\text { incompleto. }\end{array}$ \\
\hline $\begin{array}{l}\text { Fórum estadual } \\
\text { de SAN RS }\end{array}$ & Ação da Cidadania & Ação da Cidadania & Bacharel \\
\hline $\begin{array}{l}\text { Fórum estadual } \\
\text { de SAN RS }\end{array}$ & ONG Maria Mulher & $\begin{array}{l}\text { Movimento Feminista; ONG; Igre- } \\
\text { ja; Movimento Negro }\end{array}$ & Bacharel \\
\hline $\begin{array}{l}\text { Fórum estadual } \\
\text { de SAN RS }\end{array}$ & Ação da Cidadania & Movimento social & Bacharel \\
\hline Força Sindical & & $\begin{array}{l}\text { Conselho da Mulher; Conferência } \\
\text { do Meio Ambiente }\end{array}$ & $\begin{array}{l}\text { Ensino } \\
\text { técnico }\end{array}$ \\
\hline Lions Club & & Não citou nenhuma & $\begin{array}{l}\text { Doutorado } \\
\text { imcompleto }\end{array}$ \\
\hline
\end{tabular}

Fonte: dados das entrevistas (2007) in Moura (2009). 
Democratização ou assimetria da representação: notas sobre os Conselhos Estaduais de Segurança Alimentar e Nutricional

Joana Tereza Vaz de Moura • Lorena Madruga Monteiro

Quadro 6 - Trajetória associativa e formação escolar dos conselheiros da sociedade civil no Consea CE

\begin{tabular}{ccc}
\hline $\begin{array}{c}\text { Entidade que } \\
\text { representa }\end{array}$ & Demais entidades de que participou e/ou participa & $\begin{array}{c}\text { Formação } \\
\text { escolar }\end{array}$ \\
\hline Cáritas & ONG ASA; Fórum cearense para o semi-árido & Bacharel \\
\hline $\begin{array}{c}\text { Federação da } \\
\text { Agricultura CE }\end{array}$ & Não citou nenhuma & Mestrado \\
\hline $\begin{array}{c}\text { Assembléia Legislativa } \\
\text { Universidade Federal } \\
\text { do Ceará }\end{array}$ & $\begin{array}{c}\text { Partido político; Conselho Estadual de Saúde; } \\
\text { Conselho da Escola de Saúde Pública }\end{array}$ & Phd \\
\hline $\begin{array}{c}\text { Universidade Estadual } \\
\text { do Ceará }\end{array}$ & Conselho de nutricionistas & Doutorado \\
\hline COEP & Movimento social; Ação da Cidadania; Fundação & Banco do Brasil \\
\hline Fórum Cearense de & Pastoral da criança; ONG Vida Brasil & Bacharel \\
\hline SAN & Orçamento Participativo de Fortaleza; Sindicato de \\
NESC CE & Movitricionistas & Bacharel \\
\hline Rotary & $\begin{array}{c}\text { Conselho de Direito da Criança e do Adolescente; } \\
\text { Conselho Municipal de Assistência Social }\end{array}$ & Bacharel \\
\hline
\end{tabular}

Fonte: dados das entrevistas (2007) in Moura (2009).

No entanto, o ingresso em vários tipos de militância associativa desses conselheiros tem relação com o desenvolvimento de sua carreira profissional. Nesse sentido, esse fato não inviabiliza e até incrementa aquelas proposições as quais relacionam maior escolaridade com maiores disposições para a militância associativa, mas refere-se a um tipo particular de uma militância associativa: a especializada. Como relata uma Conselheira ligada à Universidade Estadual do Ceará.

Em termos de minha trajetória eu sempre trabalhei com grupos populacionais e com a representação de classe. Porque quando da minha formação eu fui para a região norte e trabalhei 09 anos no Amazonas. Sempre trabalhei na questão de formar entidades 
representativas dos profissionais, criamos, fomos representante de conselhos de nutricionistas lá, eu fui a primeira turma de mestrado, trabalhei com crianças pré-escolares, com crianças de uma cidade à beira do Rio madeira, fiz diagnóstico nutricional dessas crianças, mas também trabalhei com idosos, adolescentes, nós fizemos algumas pesquisas com grupos populacionais, durante o mestrado e eu era nutricionista de um hospital, sobre doenças tropicais, sempre ligado à pesquisa.

Tal padrão de militância mais efetiva a partir da carreira profissional é confirmado por um representante da Cáritas, como abaixo:

Depois que eu me formei eu comecei a trabalhar no interior do Rio Grande do Norte, num projeto de assentamento de reforma agrária, na época pelo projeto Lumiar. Depois disso a Cáritas fez uma seleção e estou aqui há quase sete anos.

Portanto, o modo como são escolhidos os representantes, as formas de consultas às bases, assim como suas trajetórias, considerando a formação educacional e a sua militância associativa revelam como se relacionam com suas bases, e como ocorre o processo de representação nos Conseas. Nessa direção, os dados analisados indicaram que, por um lado, certos representantes atuam como um grupo que detém o monopólio do conhecimento técnico sobre a segurança alimentar, e, por outro lado, outros atuam de forma individual, como "personalidades" indicadas, que não tem relação nenhuma com as bases e nem com a causa que defendem.

\section{Considerações finais}

As principais indicações obtidas demonstraram que, ao contrário da representação eleitoral tradicional, na representação política da sociedade civil, nesses conselhos os representantes têm legitimidade pelo reconhecimento acerca de seu grau de competência e qualificação, e não necessariamente do vínculo direto com a base. Muitos representantes se constituem como detentores do saber sobre SAN, formando uma espécie de elite política que tem dificuldades em dialogar com os setores tradicionalmente excluídos e, mais ainda, se transformam em "personalidades" detentoras desse 
poder; sob essa ótica, não se preocupam em ter um respaldo da base, pois são os conhecedores da temática.

Observou-se, também, que a experiência de estruturação dos Conselhos, principalmente os de Segurança Alimentar e Nutricional, ainda é algo recente em nossa sociedade, e sua importância não esconde suas ambiguiidades e contradições. Ao contrário, tem sido grande a polêmica sobre o seu significado político, as consequiências de sua institucionalização e a participação da sociedade civil.

O que se verifica na prática é a fragilidade dos conselheiros diante da centralização do poder nas mãos de alguns poucos, especialmente daqueles especialistas no tema de SAN. Mesmo que as presidências dos Conseas sejam preferencialmente exercidas por representantes da sociedade civil e que incentivem a participação e a discussão, muitos representantes pouco se manifestam, pouco discordam das opiniões do presidente. Muitas vezes a figura do presidente, numa postura centralizadora e autoritária, dificulta e até impede os debates, forçando consensos.

Ainda que a participação de determinados segmentos da sociedade civil nos Conselhos, através de seus representantes, potencialize a inserção destes nas discussões referentes ao tema da SAN, as comunidades e grupos que não se reúnem e aqueles que não se organizam, como é o caso de milhares de pessoas que passam fome, não terão seus interesses contemplados nas discussões. Perde-se assim a discussão fundamental para a construção dos interesses coletivos.

Com relação à questão da representatividade, os conselhos estudados também se constituem como espaços em que os representantes mantêm certo distanciamento da base. O vínculo do representante com os demais participantes das organizações sociais é bastante frágil, já que acontece ocasionalmente e por meio de reuniões esporádicas para informes e repasses. Assim, a hipótese de que os representantes conservam em suas decisões certa independência frente à base pode ser confirmada. Isso não quer dizer que não exista uma legitimidade da representação. Porque, ao contrário da representação eleitoral tradicional, em que o representante (eleito) deve se identificar com o representado (eleitor), na representação política coletiva, os representantes podem ter legitimidade pelo 
reconhecimento acerca de seu grau de competência e qualificação, e não necessariamente pelo vínculo direto com a base.

Acredita-se que essas indicações, ainda que preliminares, acerca da questão da representação nos Conseas tragam novos modos de ver a participação social nessas inovações institucionais. Nessa direção, não apenas os Conselhos de criação recente, como os de Segurança Alimentar, mas principalmente aqueles que de certa forma já são consolidados e socialmente reconhecidos, como os de Saúde, devem ser repensados a partir de sua representação. Portanto, o que de fato deve ser ressaltado é que se deve pensar em novas formas de prestação de contas e de relações entre representantes e representados.

Recebido em 23.12.2009

Aprovado em 11.03.2010

\section{Referências}

ABRAMOVAY, R. Conselhos além dos limites. In: Revista Estudos Avançados, vol. 15, n. 43. São Paulo: USP, 2001

ALMEIDA, M.H.T. de. Federalismo e Política Sociais. In: Revista Brasileira de Ciências Sociais, n. 28. São Paulo: Hucitec, 1995.

ARRETCHE, M. Mitos da descentralização: mais democracia e eficiência nas políticas públicas? In: Revista Brasileira de Ciências Sociais, n.31. São Paulo: Hucitec, 1996.

AVRITZER, L. Participação política em São Paulo. São Paulo: UNESP, 2004.

. A participação social no Nordeste. In: AVRITZER, L. (Org.). A participação social no Nordeste. Belo Horizonte: UFMG, 2007.

BARREIRA, I.A.F. Modernização política e questão social. Diagramas do poder local. In: Caderno CRH, vol. 07, n. 20. Salvador, UFBA, 1994.

BOSCHI, R. Descentralização, clientelismo e capital social na governança urbana: comparando Belo Horizonte e Salvador. In: Dados, vol.42, n.4. Rio de Janeiro: IUPERJ, 1999. 
BOURDIEU, P. Razões práticas. Sobre a teoria da ação. Campinas: Papirus, 1996. 1998.

. O Poder Simbólico. 2.ed. Rio de Janeiro: Bertrand Brasil, . In other Words: Essays towards a reflexive Sociology. Cambridge: Polity Press, 1990.

CHAIA, V. \& TÓTORA, S. Conselhos municipais e a institucionalização da participação política: a Região Metropolitana de São Paulo. In: SANTOS JUNIOR, O.A.; RIBEIRO, L.C.Q. \& AZEVEDO, S.de. (Org.) Governança democrática e poder local. A experiência dos conselhos municipais no Brasil. Rio de Janeiro: Revan, FASE, 2004.

CONSEA. Oficio N. 070- 2007.

CORTES, S. Fóruns participativos e governança: uma sistematização das contribuições da literatura. In: LUBAMBO, C.; COELHO, D. \& MELO, M.A. (Org.). Desenho institucional e participação política: experiência no Brasil contemporâneo. Petrópolis: Vozes, 2005.

. Perfil dos delegados da 10a Conferencia Nacional de Saúde. In: Conferencia Nacional de Sáude On Line. 2007. Disponível em www.datasus.gov.br/cns/documentos/Perfildelelegados10.htm. Acessado em $10 \mathrm{dez} 2008$.

COSTA, S. Contextos da construção do espaço público no Brasil. In: Novos Estudos CEBRAP, no 47, março, 1997.

DAGNINO, E. Sociedade civil, espaços públicos e a construção democrática no Brasil: limites e possibilidades. In: DAGNINO, E. (org). Sociedade civil e espaços públicos no Brasil. São Paulo: Paz e Terra, 2002.

. Sociedade civil, Participação e cidadania: de que estamos falando? In: MATO, D. (Coord.) Políticas de ciudadanía y sociedad civil en tiempos de globalización. Caracas: FACES, Universidad Central de Venezuela, 2004.

DAHL, R. Who Governs? New Haven: Yale University, 1961.

DISCH, L. Representation "Do's and Dont's": Hanna Pitkin's The concept of representation, 2005. Disponível em: www.univ-paris8. fr/scpo/lisadisch.pdf. Acessado em 10 jan 2007. 
DOIMO, A.M. A Vez e a Voz do Popular: Movimentos sociais e participação política no Brasil pós 70. Rio de Janeiro: Relume Dumará, 1995.

FERRAZ, A.T.R. Impactos da experiência conselhista sobre as atividades políticas e organizativas dos movimentos sociais na saúde: o caso do movimento popular de saúde de Campinas-SP. Tese de doutorado em Ciências Sociais, Universidade Estadual de Campinas, 2005.

FILLIEULE, O. Propositions pour une analyse processuelle de l'engagement individuel: Post Scriptum. Revue Française de Science Politique, v. 51, n. 1-2, 2001.

GOHN, M.G. Conselhos gestores e participação sóciopolítica. São Paulo: Cortez, 2003.

KIYOTA, N. A Representação dos agricultores familiares em espaços de participação social no sudoeste do Paraná. Tese de doutorado em Desenvolvimento Rural. Porto Alegre: PGDR/UFRGS, 2007.

LÜCHMANN, L.H. Os sentidos e desafios da participação. XXI Congresso Brasileiro de Sociologia - SBS. Belo Horizonte: UFMG, 2005.

. A representação no interior das experiências de participação. Lua Nova, n. 70, 2007.

MATONTI, F. \& POUPEAU, F. Le capital militant: essai de définition. Actes de la Recherche en Sciences Sociales, n. 154, 2004.

MOURA, J.T.V. A representação política de organizações da sociedade civil nos Conselhos de Segurança Alimentar e Nutricional e a busca pela legitimidade. Tese de Doutorado em Ciência Política. Porto Alegre: UFRGS, 2009.

OFFE, C. \& WIESENTHAL, H. Duas lógicas da ação coletiva: notas teóricas sobre a classe social e a forma de organização. In: OFFE, C. Problemas estruturais do estado capitalista. Rio de Janeiro: Tempo Brasileiro, 1984.

PINTO, C.R.J. ONGs, exclusão e política no Brasil. (mimeo), 2003. . Espaços deliberativos e a questão da representação. In:

Revista Brasileira de Ciências Sociais, vol.19, n.54. São Paulo: Hucitec, 2004a. 
. A sociedade civil institucionalizada. Política e Sociedade, vol.5. Florianópolis: UFSC, 2004b.

PITKIN, H.F. The concept of representation. Berkeley, CA, Los Angeles, CA and London: University of California, 1967.

. Representação: palavras, instituições e idéias. In: Lua Nova. Revista de Cultura e Política. № 67, 2006.

PUTNAM, R. 1976. The comparative study of political elites. New Jersey: Prentice- Hall, 1976.

SADER, E. Quando novos personagens entraram em cena: experiências, falas e lutas dos trabalhadores da Grande São Paulo (1970-1980). Rio de Janeiro: Paz e Terra, 1988.

SANTOS, B.S. (Org.). Democratizar a democracia: os caminhos da democracia participativa. Rio de Janeiro: Civilização Brasileira, 2002.

SANTOS JUNIOR, O.A.; RIBEIRO, L.C.Q. \& AZEVEDO, S. (Org.) Governança democrática e poder local. A experiência dos conselhos municipais no Brasil. Rio de Janeiro: Revan, FASE, 2004.

SANTOS, M.R.M. A representação social no contexto da participação institucionalizada. O caso dos conselhos municipais do Rio de Janeiro. In: SANTOS JUNIOR, O.A.; RIBEIRO, L.C.Q. \& AZEVEDO, S. (Org.) Governança democrática e poder local. A experiência dos conselhos municipais no Brasil. Rio de Janeiro: Revan, FASE, 2004.

SILVA, M.K. Tradições associativas populares e democracia: uma análise comparativa das experiências de Orçamento Participativo na Região Metropolitana de Porto Alegre. XXIV Congresso da ALAS, 2003.

SILVA, M.K. \& MARQUES, P.E.M. Democratização e políticas públicas de desenvolvimento rural. In: SCHNEIDER, S. et al. Políticas públicas e participação social no Brasil rural. Porto Alegre: UFRGS, 2004.

SCHUMPETER, J. Capitalismo, socialismo e democracia. Rio de Janeiro: Zahar, 1984.

SIMÉANT, J., DAUVIN, P. \& C.A.H.I.E.R. Le travail humanitaire. Les acteurs des ONG, du siege au terrain. Paris: Presses de Sciences Po, 2002. 


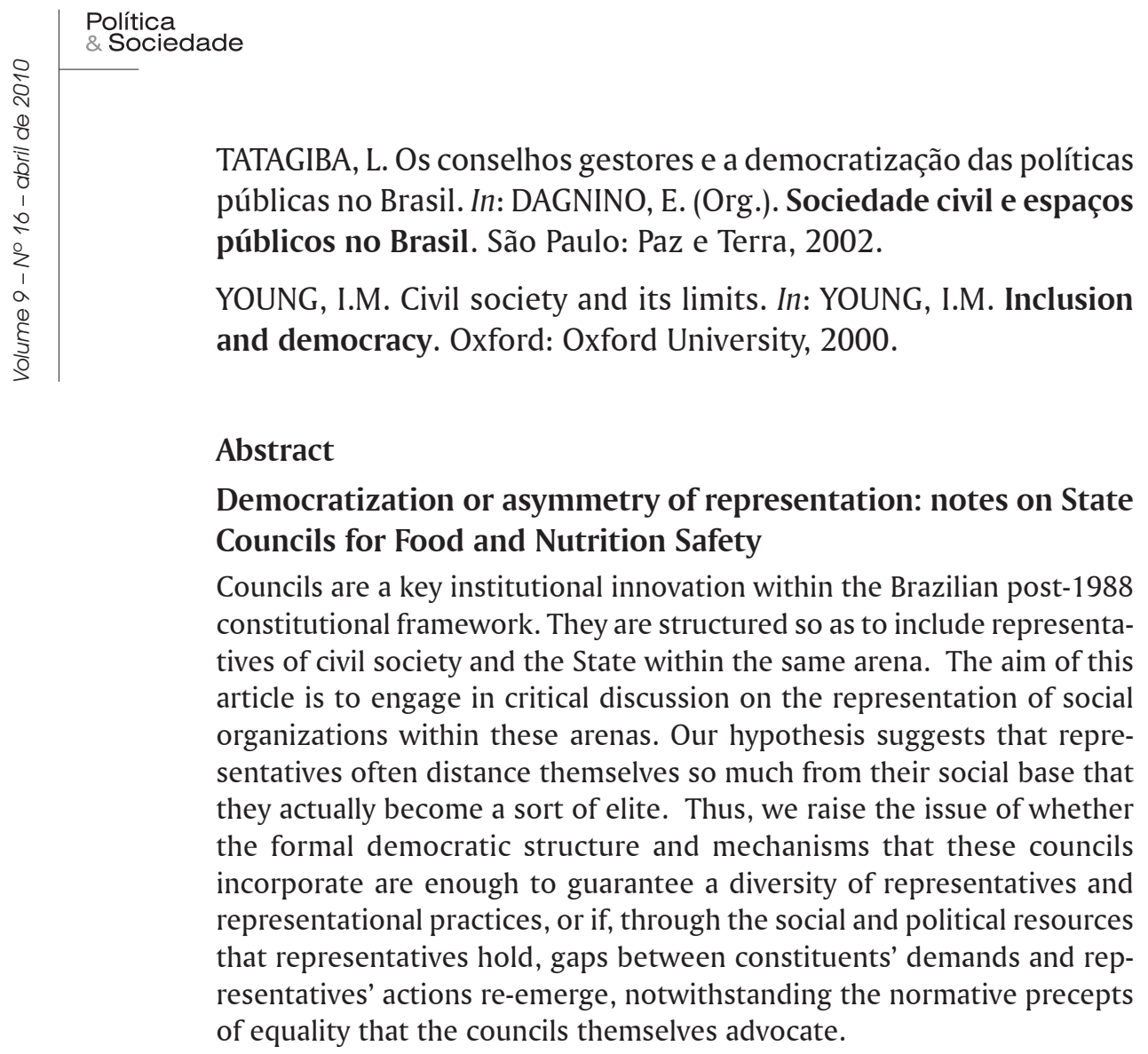

Keywords: councils, elites, representation. 